
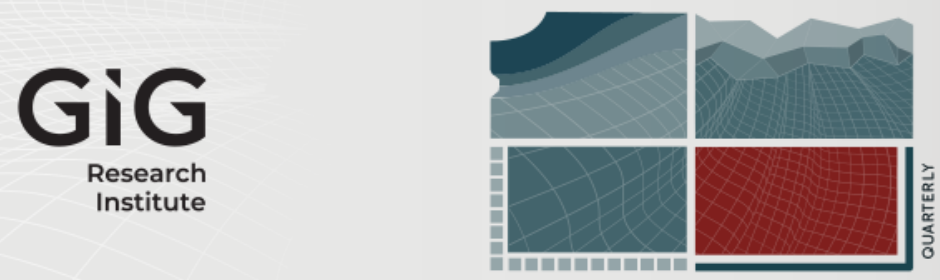

JOURNAL

OF

SUSTAINABLE

MINING

Volume 20 | Issue 1

Article 1

2021

\title{
The impact of precipitation on state of the slopes surface and thermal activity of the mine waste dump - preliminary study
}

Author(s) ORCID Identifier:

Zenon Różański (iD 0000-0002-0483-7276

Paweł Wrona (iD) 0000-0001-5978-4039

Grzegorz Pach (iD) 0000-0003-2680-3568

Adam Niewiadomski (iD) 0000-0002-4446-5059

Tomasz Suponik (D) 0000-0002-4251-4275

Robert Frączek (iD) 0000-0001-6810-5915

Follow this and additional works at: https://jsm.gig.eu/journal-of-sustainable-mining

Part of the Explosives Engineering Commons, Oil, Gas, and Energy Commons, and the Sustainability Commons

\section{Recommended Citation}

Różański, Zenon; Wrona, Paweł; Pach, Grzegorz; Niewiadomski, Adam; Suponik, Tomasz; Frączek, Robert; and Balcarczyk, Leszek (2021) "The impact of precipitation on state of the slopes surface and thermal activity of the mine waste dump - preliminary study," Journal of Sustainable Mining: Vol. 20 : Iss. 1 , Article 1.

Available at: https://doi.org/10.46873/2300-3960.1035

This Research Article is brought to you for free and open access by Journal of Sustainable Mining. It has been accepted for inclusion in Journal of Sustainable Mining by an authorized editor of Journal of Sustainable Mining. 


\title{
The impact of precipitation on state of the slopes surface and thermal activity of the mine waste dump - preliminary study
}

\begin{abstract}
Precipitation, especially with a high intensity, affects the condition of mining waste dumps. The article presents the results of research aimed at determining the impact of rain on water erosion on the slopes of a coal waste dump and its thermal state. Preliminary tests of the condition of two slopes of the coal waste dump in Libiąż (Poland) undertaken in the frameworks of the TEXMIN project was carried out using modern geodesy techniques (low-ceiling photogrammetry and TLS terrestrial laser scanning). The current geometry of the slope surface was faithfully reproduced in the form of a cloud of points with known coordinates $x, y, z$. The thermal state within the analyzed slopes of the dump was also assessed. Based on thermography studies and measurements of temperature and gas concentrations inside the object, two zones of thermal activity were located on one of the examined slopes. The test results constitute the initial state against which the results of further tests will be compared. This will allow to determine the influence of precipitation on the amount of water erosion and the thermal state of the dump in a specific time period.
\end{abstract}

\section{Keywords}

coal waste dump, water erosion, spontaneous combustion, low-ceiling photogrammetry, terrestrial laser scanning, thermography

\section{Creative Commons License}

\section{(c) (7)}

This work is licensed under a Creative Commons Attribution 4.0 License.

\section{Authors}

Zenon Różański, Paweł Wrona, Grzegorz Pach, Adam Niewiadomski, Tomasz Suponik, Robert Frączek, and Leszek Balcarczyk 


\title{
The impact of precipitation on state of the slopes surface and thermal activity of the mine waste dump - preliminary study
}

\author{
Zenon Różański ${ }^{a}{ }^{*}$, Paweł Wrona ${ }^{a}$, Grzegorz Pach ${ }^{a}$, Adam Niewiadomski ${ }^{\text {, }}$ \\ Tomasz Suponik ${ }^{a}$, Robert Frączek ${ }^{b}$, Leszek Balcarczyk ${ }^{c}$ \\ a Silesian University of Technology, Faculty of Mining, Safety Engineering and Industrial Automation, Poland \\ b TAURON Wydobycie S.A., Geology Department, Poland \\ ${ }^{c}$ 3D FORMAT Sp. J., Poland
}

\begin{abstract}
Precipitation, especially with a high intensity, affects the condition of mining waste dumps. The article presents the results of research aimed at determining the impact of rain on water erosion on the slopes of a coal waste dump and its thermal state. Preliminary tests of the condition of two slopes of the coal waste dump in Libiąż (Poland) undertaken in the frameworks of the TEXMIN project was carried out using modern geodesy techniques (low-ceiling photogrammetry and TLS terrestrial laser scanning). The current geometry of the slope surface was faithfully reproduced in the form of a cloud of points with known coordinates $x, y, z$. The thermal state within the analyzed slopes of the dump was also assessed. Based on thermography studies and measurements of temperature and gas concentrations inside the object, two zones of thermal activity were located on one of the examined slopes. The test results constitute the initial state against which the results of further tests will be compared. This will allow to determine the influence of precipitation on the amount of water erosion and the thermal state of the dump in a specific time period.
\end{abstract}

Keywords: coal waste dump, water erosion, spontaneous combustion, low-ceiling photogrammetry, terrestrial laser scanning, thermography

\section{Introduction}

$\mathrm{P}$ recipitation is an important factor influencing the condition of mining waste dumps. In addition to the leaching of contaminants from waste, precipitation contribute to the erosion of the slopes and, as a result, to the formation of numerous erosive gullies on the slopes [1]. This phenomenon may also have an adverse effect on the thermal condition of the object. Under the influence of rainfall, the fine grains of the heaped material are successively flushed (ablated) from the inclined slopes of the dump. This phenomenon may be linear, superficial or diffuse.
In the case of linear flushing, gullies form, which deepen with time and intensity of rainfall. Additionally, there is a phenomenon of transporting fine grains along with water penetrating into the dump. As a result of this phenomenon, the zone of wind aeration and water infiltration deepens. The naturally occurring low temperature oxidation of carbon contained in waste in the presence of oxygen from air and water is intensified. It is a complex process involving the following phenomena [2]: oxygen transport to the surfaces of coal particles, oxygen transport, within coal pores (pore diffusion), chemical interaction between coal and oxygen, and release of heat and emission of gaseous products. The main products observed during the low-temperature oxidation of coal are $\mathrm{CO}_{2}, \mathrm{CO}, \mathrm{H}_{2} \mathrm{O}$,

Received 13 November 2020; revised 18 December 2020; accepted 28 December 2020.

Available online 6 March 2021

* Corresponding author.

E-mail address: zenon.rozanski@polsl.pl (Z. Różański). 
hydrocarbons $\left(\mathrm{C}_{x} \mathrm{H}_{y}\right)$ [3-6]. The concentrations of these gases together with the loss of oxygen inside the heap are usually used as indicators of thermal activity. Important role in the self-heating coal wastes dumping sites play an iron sulphides $\mathrm{FeS}_{2}$ in the form of pyrite or marcasite. They also undergo chemical reactions in the presence of oxygen and moisture, which release some heat $[7,8]$. Their participation in the waste colliery spoils is much lower than coal, but the reactions that accompany have more exothermic nature. Under appropriate conditions, at depths where there is a possibility of heat accumulation, this leads to the development of an endogenous fire. The phenomenon of spontaneous combustion of coal waste dumps is complex and depends on many factors $[2,9,10]$. However, the access of oxygen is a necessary condition to fire. As a result of chemical reactions and the increase in temperature inside the dump, a thermal depression arises, which forces air to be sucked in from the atmosphere.

On the other hand, the warm products of chemical reactions are carried outside according to the chimney draft principle. In this way, a natural mechanism forcing air circulation and the exhalation of fire gases is created. The slopes of dumps are a frequent place of thermal processes [11].

Thermal activity of coal waste dump has a negative impact on the immediate surroundings and causes the emission of fire gases into the atmosphere. Dust and fire gases are released, including odors and toxic gases [11-14]. An additional source of danger is the high temperature accompanying dump fires, exceeding even $800^{\circ} \mathrm{C}$ at shallow depths.

The location and measurement techniques of modern geodesy used in recent years provide excellent opportunities for examining the condition of various types of surfaces [15-19]. Low-ceiling photogrammetry and laser scanning (TLS) also allow for precise geometric mapping of the surface of waste dumps [20-22]. The applied measurement methods allow for obtaining much greater accuracy than traditional geodetic methods. TLS allows to obtain a grid of measurement points of the tested object with a much higher density [23]. This allows for a more precise mapping of the tested surfaces. The use of an unmanned aerial vehicle (UAV) for photogrammetric purposes with an appropriate photographic camera allows to obtain a faithful, non-generalized model of the terrain, which is perfect for any cubature calculations [24]. Depending on the flight parameters, the size of the terrain pixel of the pictures taken may be even a few millimeters. However, most often it is a centimeter size.
One of the tasks carried out under the TEXMIN project (The impact of extreme weather events on mining operations) is to assess the impact of precipitation, especially heavy rainfall, on the condition of slopes of mining waste dumps. The aim of the preliminary studies carried out in the framework of the project was to illustrate the initial state of the tested dumping ground surfaces and the thermal state of selected slopes. The test results are the starting point for the results obtained in subsequent measuring cycles. On their basis, the changes that take place in the studied areas in relation to the occurring water erosion and possible thermal activity will be assessed. Subsequent examination of the surface of the slopes will be carried out after approx. 6 and 12 months from the first measuring cycle. Observations of the atmospheric conditions in the months after the first measurement cycle allowed to determine the occurrence of both heavy rainfall and long-term rainfall.

\section{Materials and methods}

The subject of the research is the coal waste dump of ZG Janina TAURON Wydobycie S.A. The dumping ground is located in Libiazz. The object has a surface area $33.51 \mathrm{ha}$, and the storage capacity is approx. 6 million $\mathrm{m}^{3}$ (approx. 11 million $\mathrm{Mg}$ ). This is an above-ground dump and contains two parts (Fig. 1):

- fine-grain waste settler along with bunds made of coal gangue,

- coarse waste (gangue) dump.

The slopes of the dump and the embankments of the settling pond have a gentle inclination, not exceeding $30^{\circ}$. However, such a slope, in the absence of an appropriate drainage system and biological cover, favors intensive runoff of rainwater along the fall line. Such features make the ZG Janina TAURON Wydobycie S.A. landfill is significantly exposed to erosive phenomena, which justifies its choice as the subject of research under the project. Currently, the effects of water erosion are clearly visible in many areas of the slopes. At the beginning of 2020, a fragment of the western slope of the dump was covered with an approx. 1-2-meter layer of fresh waste and shaped at an angle not exceeding $15^{\circ}$. Symptoms of thermal activity have been observed in the past in this area.

Rock waste in the dump and within the embankments of the settling pond was stored in a non-selective manner, consisting in mixing coarse-grained waste with fine-grained ones. The waste was placed in layers with a thickness of approx. $1.0 \mathrm{~m}$ and 


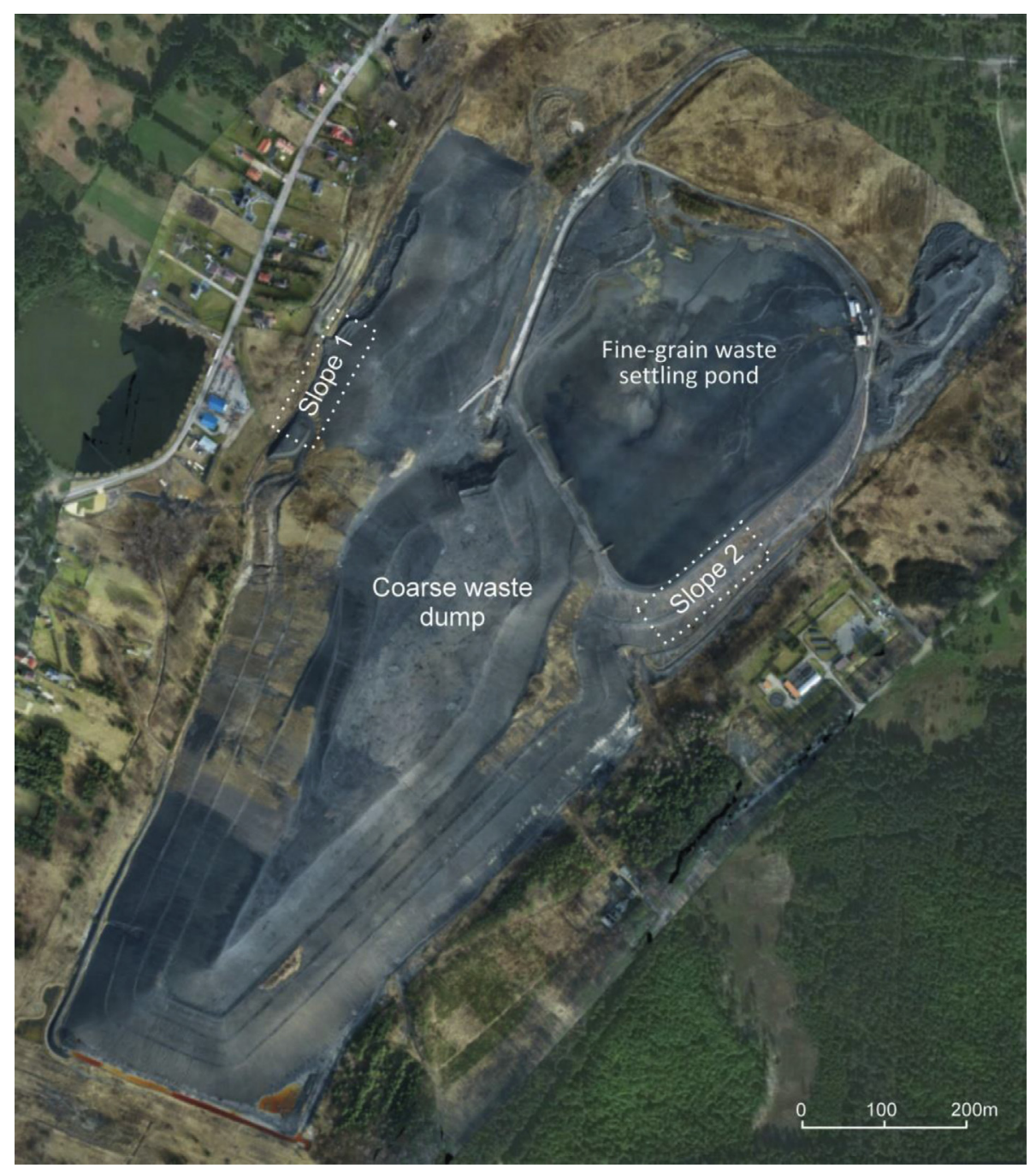

Fig. 1. The ZG Janina TAURON Wydobycie S.A. dumping ground in Libiaż and localization of analyzed slopes.

compacted with a vibrating roller to the compaction indicator $I_{S}=0.90$. Such a method of waste storage was intended to prevent the occurrence of selfheating process, and hence occurrence of endogenous fires. However, taking into account the current experience in combating fire hazard in dumps, the recommended value of the density index is $\mathrm{I}_{S} \geq 0.95$.

Waste from access and preparatory works is fragmented sandstone and shale accompanying coal seams with a vast majority of sand fraction content ( $87 \%$ of the fraction below $2 \mathrm{~mm}$, including the sand fraction $-69 \%$; the silt fraction $13 \%$; the clay fraction $13 \%)$. The thicker lumps are sandstone crumbs. This material contains slight admixtures of coal shale $(\sim 0,5 \%)$. The waste from preparatory works is mainly dark gray claystone (over $90 \%$ ), the rest are silt and sandstones (about 10\%). The content of combustible components in this waste is only $1.59 \%$.
While the rock waste from the mechanical coal processing plant, i.e. waste from coal sorting and enrichment processes, consists of clay rock crumbs (claystone and coal shale) and sandstones. Weathered waste with a lying period of several years consists of fragments of clay rocks (clayey and coal shales) and sandstone, bonded by clay weathered. They contain $33 \%$ of coarse-grained fractions and $67 \%$ of fine-grained fractions (including sand fraction $28.5 \%$; silt fraction $22.5 \%$; clay fraction $16 \%$ ). The research showed a significant content of combustible parts of $22.4 \%$ in processing waste.

Within the project, the slopes condition surveys are focused on two areas:

- Slope 1 - a fragment of a newly formed western slope of the gangue dump,

- Slope 2 - a fragment of the south-eastern slope of the settler. 


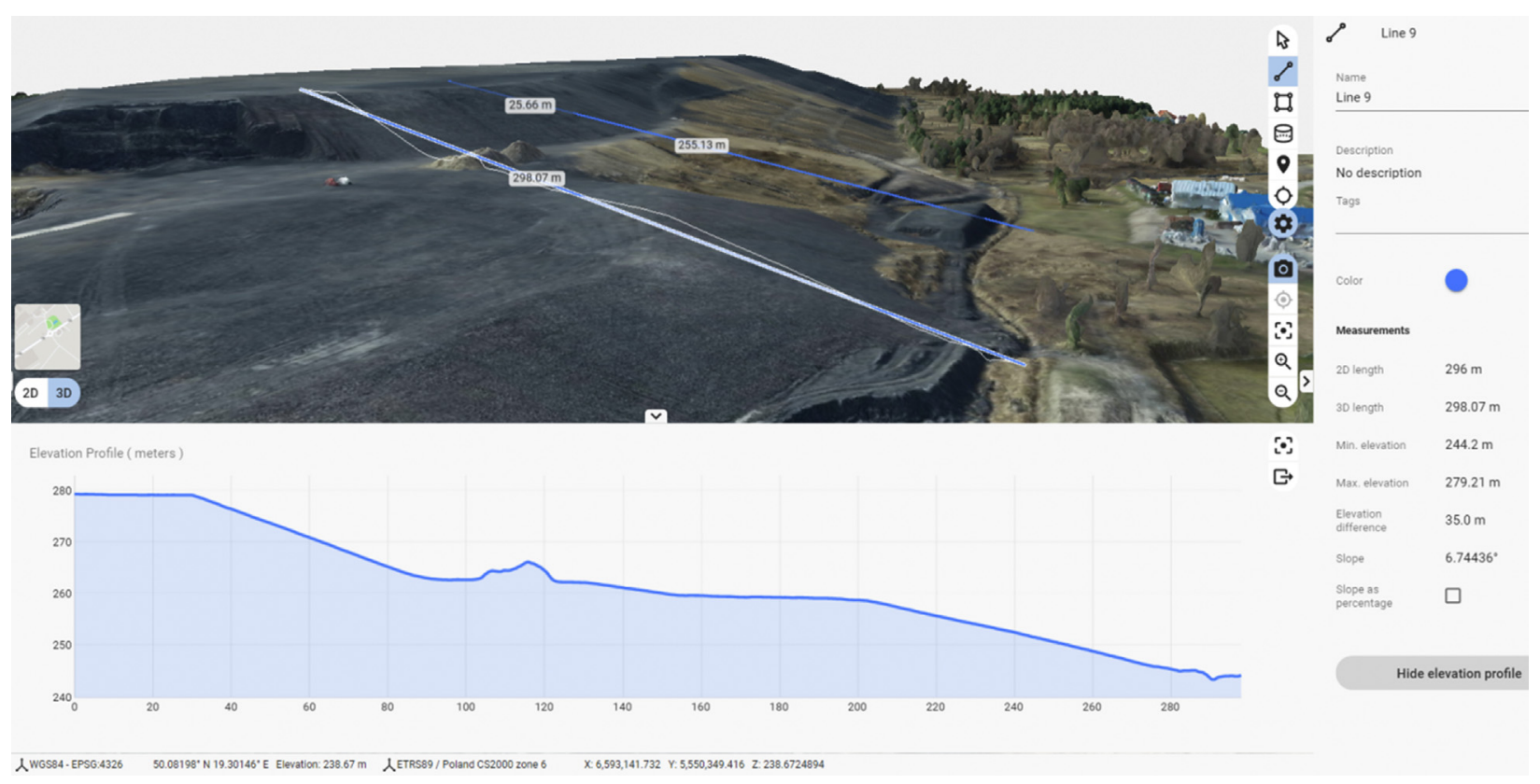

Fig. 2. The 3D model of Janina TAURON Wydobycie S.A. coal waste dump and an exemplary profile of the western slope.

The aim of the study was to illustrate the initial state of the tested dumping ground surfaces and the thermal state of selected slopes. The first photogrammetric flight and laser scanning were made on March 9, 2020. This allowed for the obtaining of point clouds presenting a geometric representation of the surface of the examined slopes of the dump. At that time, the thermal condition of both slopes was also examined.

The following methods, consisting of field and office works, were used to determine the condition of the dump slopes and settler slopes.
1) Low-altitude aerial photogrammetry using unmanned aerial vehicle UAV - DJI Phantom 4Pro RTK,

- marking photo points - measurement of terrain coordinates using GPS,

- UAV flight with the photograph of the examined dumping ground using a highresolution camera $(20 \mathrm{Mpx})$,

- preparing orthophotomap of the entire dump and matching into the Polish Coordinate System 2000 using Pix4D Mapper software,

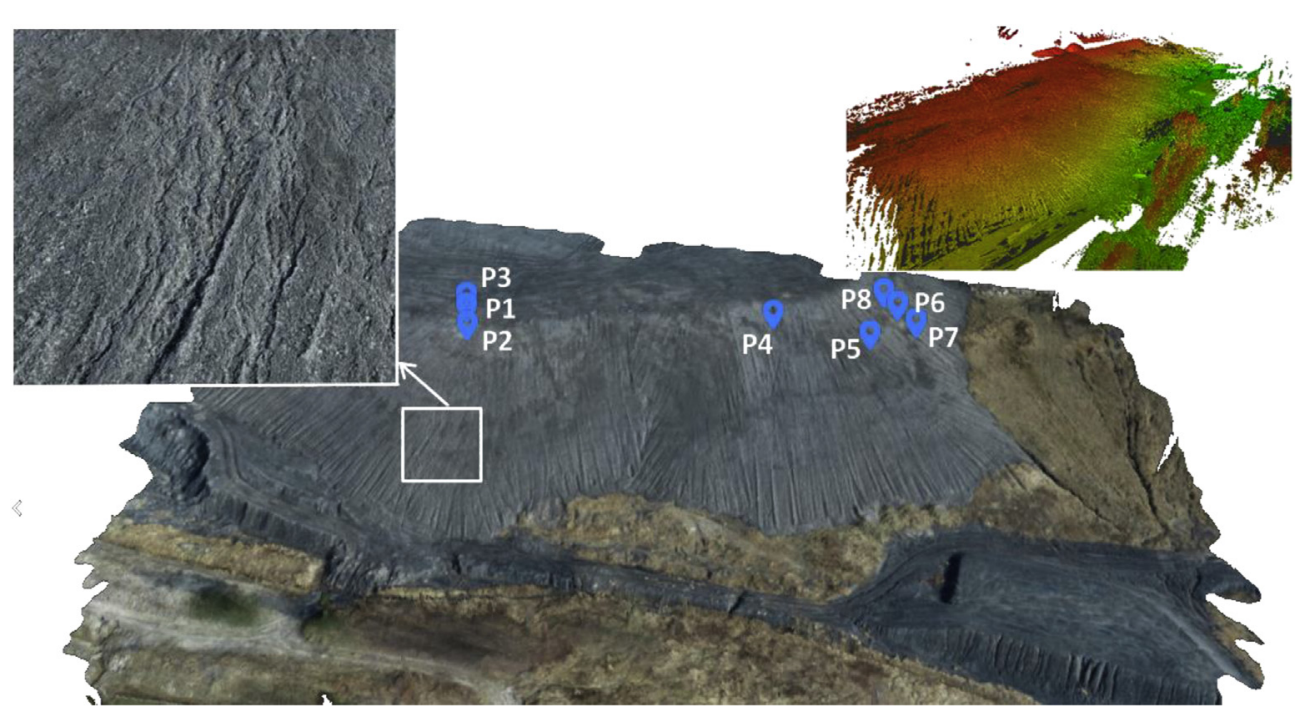

Fig. 3. Slope 1 model obtained by photogrammetry with the location of measurement points. The cloud of points obtained by TLS (top right corner). 


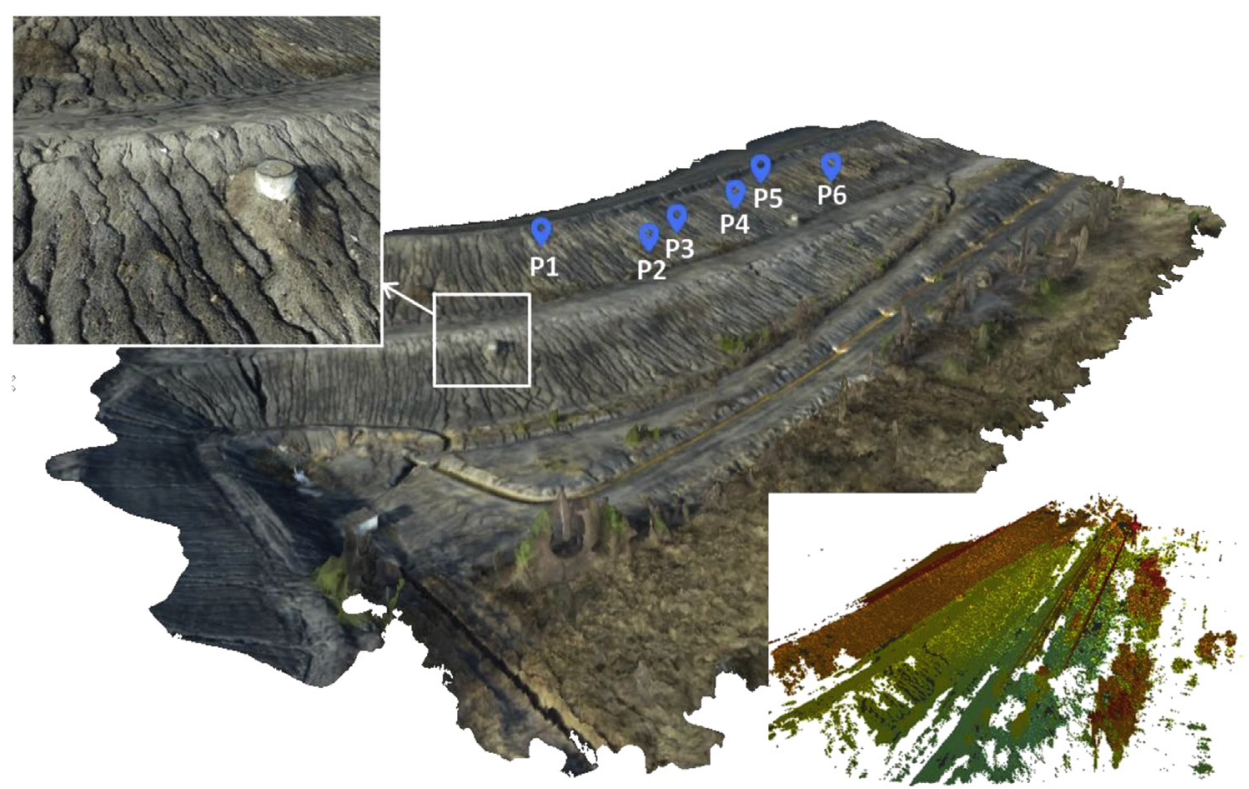

Fig. 4. Slope 2 model obtained by photogrammetry with the location of measurement points. The cloud of points obtained by TLS (bottom right corner).

- 3D cloud point rendering of the dumping ground surface and surfaces of two selected slopes,

- development of 3D mesh of the dump surface (3D model of the dump).

2) $3 \mathrm{D}$ terrestrial laser scanning TLS using $\mathrm{Z}+\mathrm{F}$ IMAGER 5010C scanner.

- marking points - measurement of terrain coordinates using GPS,
- 3D laser scanning of two slopes (a total of approx. 60 positions),

- development of 3D point clouds of the dump slopes surfaces.

3) Assessment of thermal state of selected slopes of the ZG Janina waste dump.

- measurements of the slopes surface temperature using Flir E6 thermal imaging camera,

- measurements of the interior temperature of the dump (depth $1.0 \mathrm{~m}$ ) at selected points
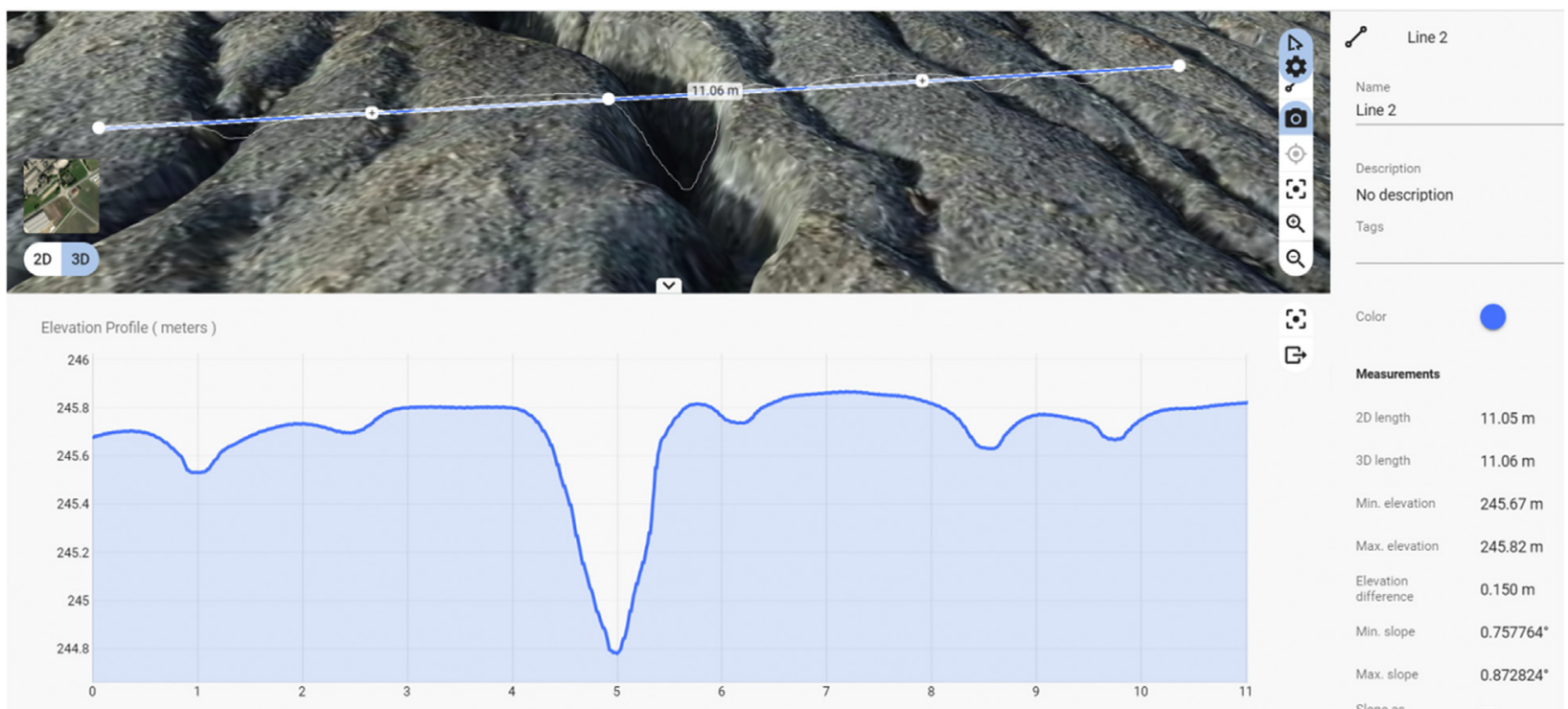

G

Fig. 5. Profile of a selected erosion gully on Slope 2. 


\begin{tabular}{|c|c|c|}
\hline \multicolumn{3}{|c|}{ Measurements } \\
\hline$B \times 1$ & $\operatorname{Max}$ & $18,1^{\circ} \mathrm{C}$ \\
\hline & Min & $0,2{ }^{\circ} \mathrm{C}$ \\
\hline & Average & $5,7^{\circ} \mathrm{C}$ \\
\hline Sp1 & & $15,7^{\circ} \mathrm{C}$ \\
\hline Sp2 & & $17,1^{\circ} \mathrm{C}$ \\
\hline Sp3 & & $10,7^{\circ} \mathrm{C}$ \\
\hline \multicolumn{3}{|c|}{ Parameters } \\
\hline Emissivity & & 0.95 \\
\hline Refl. temp. & & $5^{\circ} \mathrm{C}$ \\
\hline \multicolumn{3}{|c|}{ Note } \\
\hline \multicolumn{3}{|c|}{$\begin{array}{l}\text { Thermogram T11 } \\
\text { Upper level of the western slope } \\
\text { Self-heating zone }\end{array}$} \\
\hline
\end{tabular}
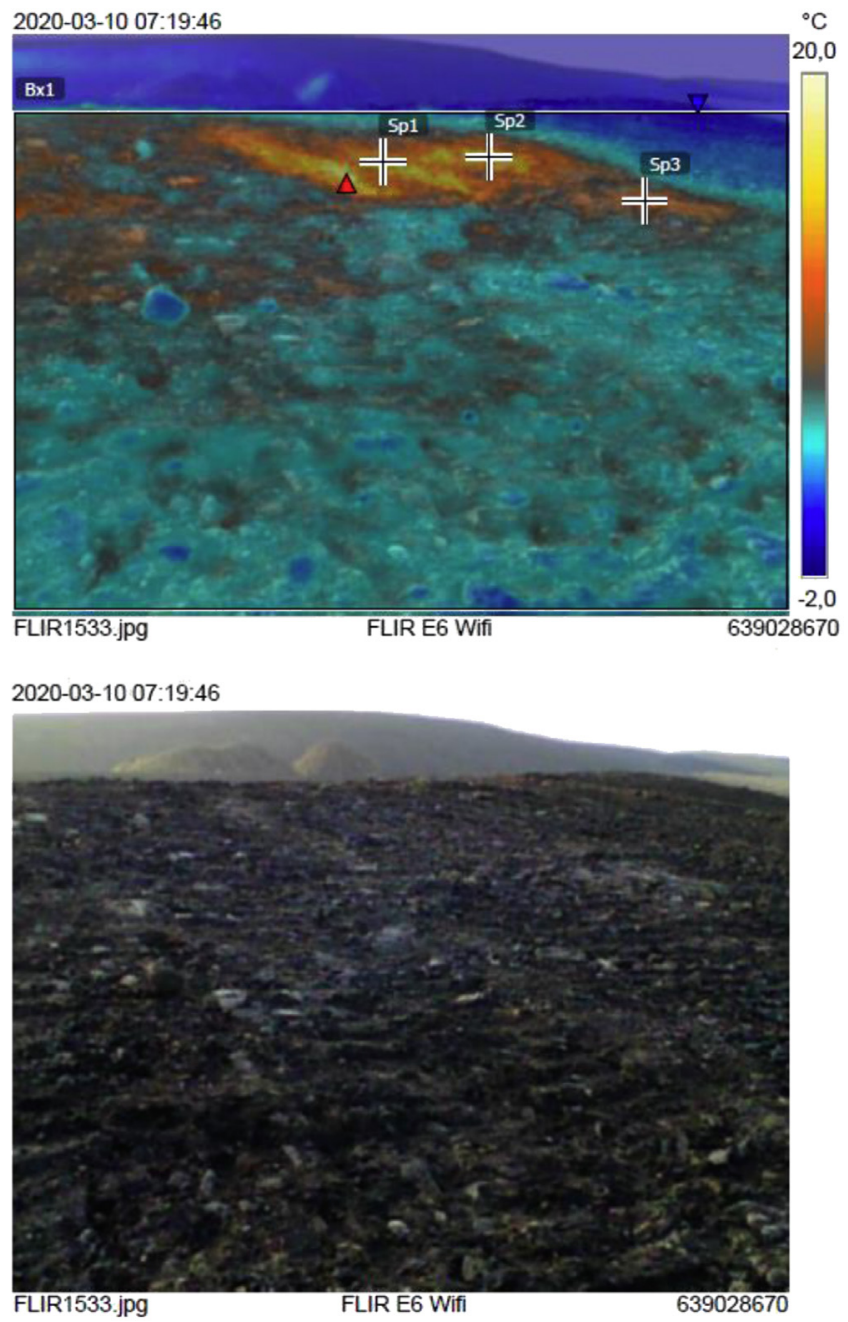

Fig. 6. Thermogram showing the Zone 1 of thermal activity on Slope 1.

using DeltaOhm HD9016 thermometer and thermocouple,

- measurements of gas concentrations (O2, $\mathrm{CO} 2, \mathrm{CO}, \mathrm{CH} 4)$ inside the dump (depth $1.0 \mathrm{~m})$ at selected points using MRUNova + gas analyzer.

As part of the project, in relation to the initial state, further tests will be performed to compare the condition of the surface. In the period after the first measurement cycle, there were heavy rains as well as less intense but long-lasting rainfall. The changes related to water erosion and thermal activity that occur over time will be determined.

\section{Results and Discussion}

\subsection{The condition of the slope surface}

The photogrammetric flight carried out on March 9, 2020 and the office works on the obtained photographic documentation allowed for the development of a detailed orthophotomap and a 3D model of the entire dump. The density of the point cloud obtained for the entire dump was 589 points per square meter and the size of the terrain pixel in the 3D model was $15.3 \mathrm{~mm}$. Using a 3D model, you can observe and analyze the surface details of an object. It is possible to define any geometrical parameters of the object and the area in its immediate vicinity, e.g. linear dimensions, surface area of any elements within the dump, topography, slope inclination, profile shape in any vertical section, vegetation coverage, etc. An exemplary view of the model is shown in Fig. 2.

The additional flights made over the slopes of Slope 1 and Slope 2 allowed for a more accurate representation of their geometry (Figs. 3 and 4). Since the photogrammetric flights over the slopes took place at a lower height, the density of the point cloud obtained for the examined slopes was 2838 points per square meter and the size of the terrain 


\begin{tabular}{|c|c|c|}
\hline \multicolumn{3}{|c|}{ Measurements } \\
\hline $\mathrm{Bx} 1$ & $\operatorname{Max}$ & $24,5^{\circ} \mathrm{C}$ \\
\hline & Min & $-2,8^{\circ} \mathrm{C}$ \\
\hline & Average & $11,1^{\circ} \mathrm{C}$ \\
\hline Sp1 & & $21,9^{\circ} \mathrm{C}$ \\
\hline Sp2 & & $20,5^{\circ} \mathrm{C}$ \\
\hline $\mathrm{Sp} 3$ & & $19,6^{\circ} \mathrm{C}$ \\
\hline \multicolumn{3}{|c|}{ Parameters } \\
\hline Emissivity & & 0.95 \\
\hline Refl. temp. & & $5^{\circ} \mathrm{C}$ \\
\hline \multicolumn{3}{|c|}{ Note } \\
\hline \multicolumn{3}{|c|}{$\begin{array}{l}\text { Thermogram T23 } \\
\text { Middle level of the western slope } \\
\text { Self-heating zone }\end{array}$} \\
\hline
\end{tabular}
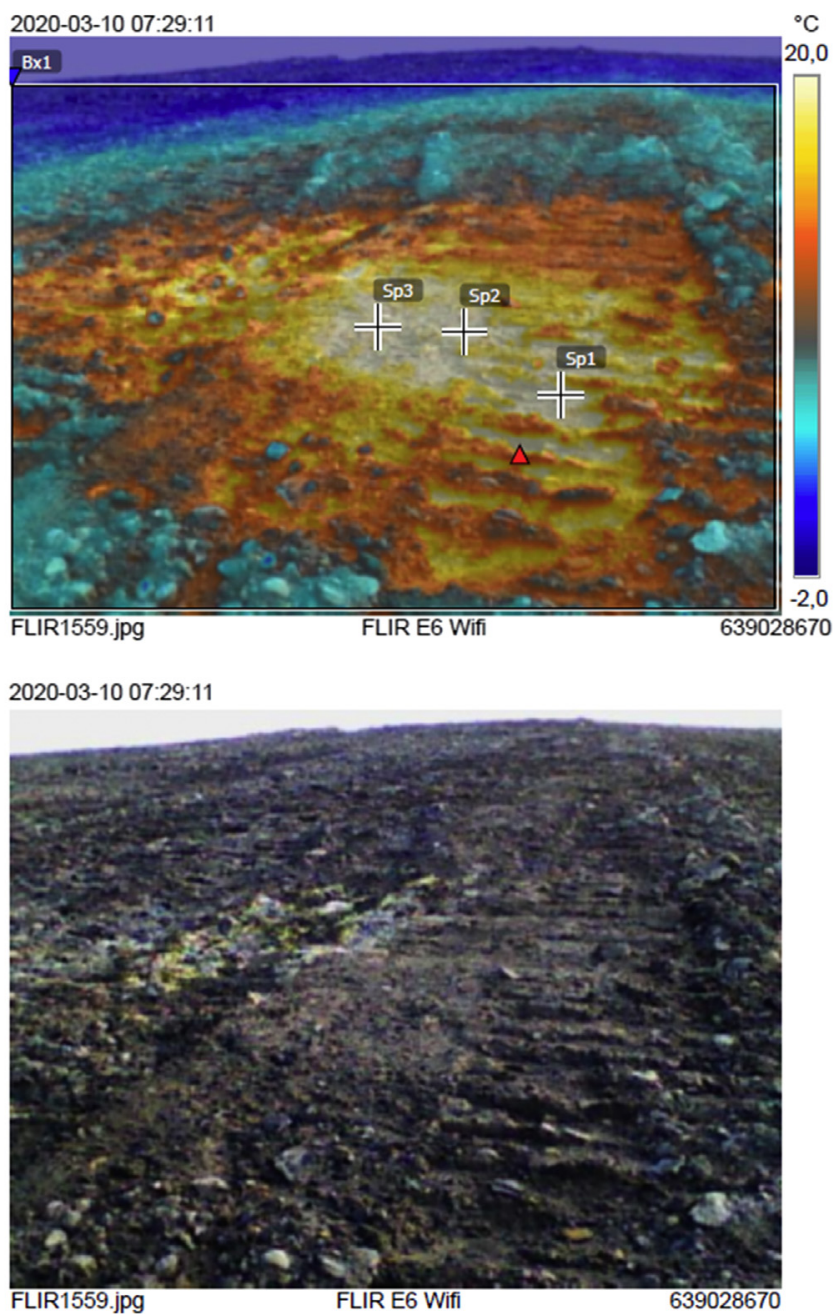

Fig. 7. Thermogram showing the Zone 2 of thermal activity on Slope 1.

pixel in the 3D model was $6.9 \mathrm{~mm}$. The 3D models of both slopes allow for the analysis of their surface condition in terms of water erosion development. For a specific initial state, individual erosion gullies can be observed in detail on the models. It is possible to determine the length, width, depth and profile of the cross section along any line (Fig. 5). Numerous erosion gullies, especially on Slope 2, have been found. The largest of them were up to $1.0 \mathrm{~m}$ deep.

The result of TLS are also point clouds representing the geometry of both slopes. The point density and the accuracy of their location are greater than in point clouds obtained with the low-ceiling photogrammetry method. The mean point cloud density was 57513 points per square meter. Examples are also presented in Figs. 3 and 4. The currently obtained point clouds will be used in the differential calculations. They will make it possible to determine the progress of water erosion on the basis of the loss of volume of the material on the slopes caused by washing out of the material grains by flowing water. It will be possible after performing subsequent measurement cycles.

\subsection{Thermal state}

The thermal state of both analyzed slopes was tested. Thermal imaging studies allowed to determine the surface temperature. Temperature and gas concentrations inside the dump were also measured on both slopes. The ambient temperature on the day of the measurements was relatively low and amounted to $5^{\circ} \mathrm{C}$. During infrared observations, two 
Table 1. Temperature and gases concentration inside Slope 1.

\begin{tabular}{|c|c|c|c|c|c|c|c|c|}
\hline \multirow[t]{2}{*}{ Measurement point } & \multicolumn{3}{|c|}{ Temperature } & \multicolumn{5}{|c|}{ Gases concentration/Oxygen loss $\left(\Delta \mathrm{O}_{2}\right)$} \\
\hline & $\begin{array}{l}\mathrm{t}_{\mathrm{p}} \\
{ }^{\circ} \mathrm{C}\end{array}$ & $\begin{array}{l}\mathrm{t}_{1,0 \mathrm{~m}} \\
{ }^{\circ} \mathrm{C}\end{array}$ & $\begin{array}{l}{ }_{t_{\text {gas }}} \\
{ }^{\circ} \mathrm{C}\end{array}$ & $\begin{array}{l}\mathrm{O}_{2} \\
\% \text { vol. }\end{array}$ & $\begin{array}{l}\Delta \mathrm{O}_{2} \\
\% \text { vol. }\end{array}$ & $\begin{array}{l}\mathrm{CO}_{2} \\
\% \text { vol. }\end{array}$ & $\mathrm{CO}$ ppm & $\begin{array}{l}\mathrm{CH}_{4} \\
\% \text { vol. }\end{array}$ \\
\hline P1 & 26.2 & 89.6 & 88.3 & 1.7 & 19.2 & 15.54 & 12120 & 0.411 \\
\hline P2 & 11.2 & 68.5 & 53.6 & 1.4 & 19.5 & 16.18 & 12280 & 0.521 \\
\hline P3 & 16.6 & 66.7 & 34.4 & 2.0 & 18.9 & 14.12 & 10420 & 0.375 \\
\hline P4 & 5.9 & 15.4 & 8.6 & 20.8 & 0.1 & 0.09 & 0 & 0.003 \\
\hline P5 & 8.5 & 13.1 & 7.8 & 20.8 & 0.1 & 0.06 & 0 & 0 \\
\hline P6 & 28.0 & 271 & 102.4 & 1.6 & 19.3 & 13.08 & 4798 & 0.028 \\
\hline P7 & 10.5 & 16.0 & 11.7 & 20.5 & 0.4 & 0.32 & 6 & 0.001 \\
\hline P8 & 17.1 & 65.5 & 54.9 & 1.3 & 19.6 & 8.47 & 2139 & 0.055 \\
\hline
\end{tabular}

thermally active sites were located on Slope 1 . These were zones that were characterized by significant temperature anomalies (more than $13^{\circ} \mathrm{C}$ ) in relation to the surroundings. They were located close to the upper edge of the escarpment. The surface temperature in Zone 1 (area of points $\mathrm{P} 1-\mathrm{P} 3$ ) reached $18.1^{\circ} \mathrm{C}$, and in Zone 2 (area of points $\mathrm{P} 6-\mathrm{P} 8$ ) $24.5^{\circ} \mathrm{C}$. Thermograms showing the temperature distribution in the zones of thermal activity are presented in Figs. 6 and 7.

The results of the temperature and gas concentration tests inside the dump on Slope 1 are presented in Table 1 . Temperature values $t_{1.0 \mathrm{~m}}$ found at $1 \mathrm{~m}$ depth reached $89.6^{\circ} \mathrm{C}$ in Zone 1 and $271^{\circ} \mathrm{C}$ in Zone 2. High gas concentrations $\mathrm{CO}_{2}=16.18 \%$ vol., $\mathrm{CO}=1.228 \%$ vol. in Zone $1, \mathrm{CO}_{2}=13.08 \%$ vol., $\mathrm{CO}=0.4798 \%$ vol. in Zone 2 and a large loss of oxygen $\Delta \mathrm{O}_{2}$, even exceeding $19 \%$ vol. confirmed the intense nature of thermal processes within Slope 1. The gas concentrations correspond to the values observed on other objects of this type in a state of thermal activity, where the oxygen concentration drops practically to zero [25]. A very high concentrations level of $\mathrm{CO}_{2}$ (over $18 \%$ vol.) and $\mathrm{CO}$ (over $1 \%$ vol.) is achieved even at relatively low temperatures $\left(60-100^{\circ} \mathrm{C}\right)$ measured at a depth of $1 \mathrm{~m}$. It proves much higher temperature values occurring at greater depths. On the surface of the slope in Zone 2, the phenomenon of native sulphur and ammonium chloride (salammoniac) crystallization in the form of yellow crystals and white coating on grains of waste material was observed (Fig. 8). Based on our own observations, as well as those described in the literature [26,27], it is known that this phenomenon occurs in conditions of high temperatures inside the dump (gas temperature above $200^{\circ} \mathrm{C}$ ). This suggests that at greater depths (deeper than $1 \mathrm{~m}$ ) in Zone 2 a higher temperature of the waste should be expected than measured.

The results of the thermographic studies showed no significant temperature anomalies on the Slope 2 (Fig. 9). Infrared observations allow to visualize even small temperature differences that occur inside erosion gullies. However, the results of gas concentration measurements indicate that chemical reactions took place inside the settling pond. Increased

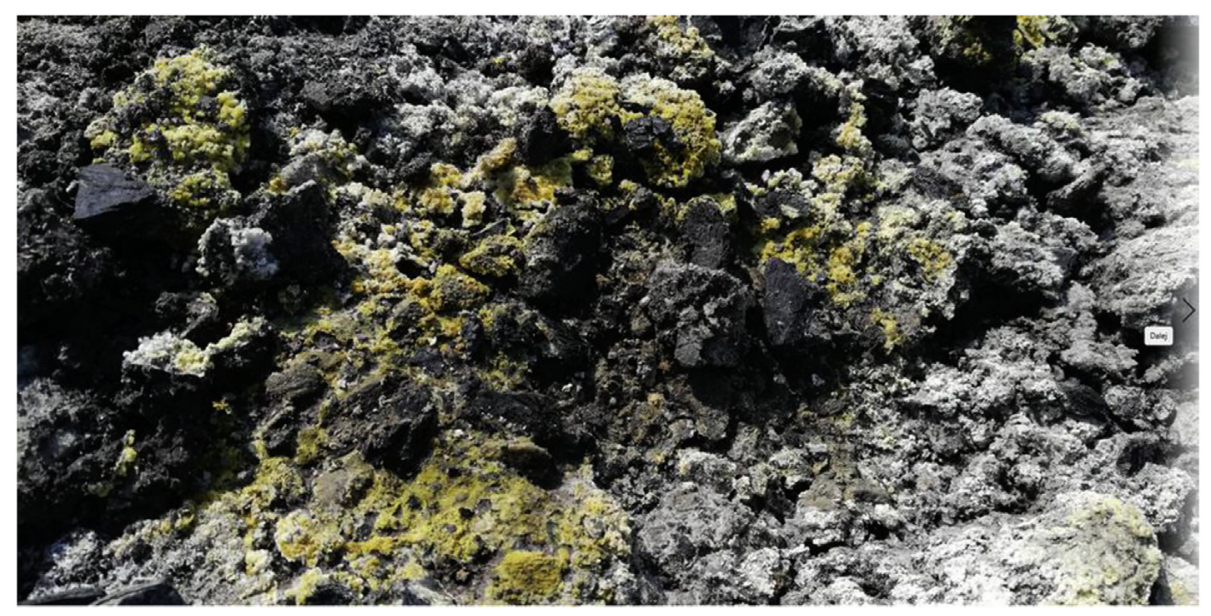

Fig. 8. Efflorescences of sulphur (yellow) and salammoniac (white) on the surface of Slope 1 in Zone 2. 


\begin{tabular}{|c|c|c|}
\hline \multicolumn{3}{|c|}{ Measurements } \\
\hline $\mathrm{Bx} 1$ & $\operatorname{Max}$ & $6,1^{\circ} \mathrm{C}$ \\
\hline & Min & $-1,0^{\circ} \mathrm{C}$ \\
\hline & Average & $2,2^{\circ} \mathrm{C}$ \\
\hline Sp1 & & $5,8^{\circ} \mathrm{C}$ \\
\hline Sp2 & & $4,9^{\circ} \mathrm{C}$ \\
\hline $\mathrm{Sp} 3$ & & $5,4^{\circ} \mathrm{C}$ \\
\hline \multicolumn{3}{|c|}{ Parameters } \\
\hline Emissivity & & 0.95 \\
\hline Refl. temp. & & $5{ }^{\circ} \mathrm{C}$ \\
\hline \multicolumn{3}{|l|}{ Note } \\
\hline \multicolumn{3}{|c|}{$\begin{array}{l}\text { Thermogram T3 } \\
\text { Upper level of the eastern slope }\end{array}$} \\
\hline
\end{tabular}

gas concentrations: $\mathrm{CO}_{2}=5.55 \%$ vol., $\mathrm{CH}_{4}=0,236 \%$ vol. and a large loss of oxygen $\Delta \mathrm{O}_{2}=17.8 \%$ vol. were found in point P6 (see Table 2). This may indicate the presence of an organic substance that is decomposing. However, these processes were not accompanied by an increase in temperature.
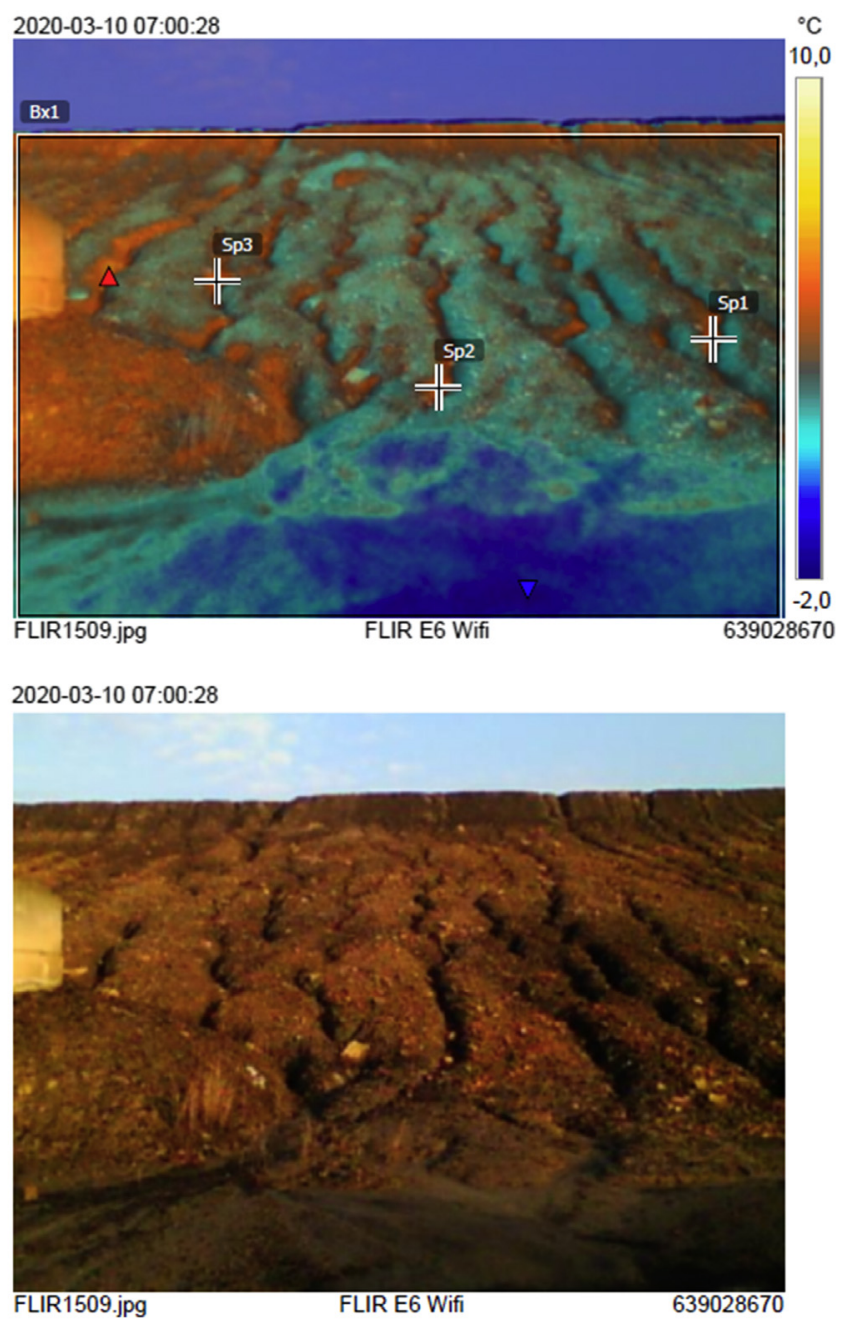

Fig. 9. Thermogram showing part of Slope 2.

Table 2. Temperature and gases concentration inside Slope 2.

\begin{tabular}{|c|c|c|c|c|c|c|c|c|}
\hline \multirow[t]{2}{*}{ Measurement point } & \multicolumn{3}{|c|}{ Temperature } & \multicolumn{5}{|c|}{ Gases concentration/Gas loss $\left(\Delta \mathrm{O}_{2}\right)$} \\
\hline & $\begin{array}{l}\mathrm{t}_{\mathrm{p}} \\
{ }^{\circ} \mathrm{C}\end{array}$ & $\begin{array}{l}\mathrm{t}_{1.0 \mathrm{~m}} \\
{ }^{\circ} \mathrm{C}\end{array}$ & $\begin{array}{l}t_{\text {gas }} \\
{ }^{\circ} \mathrm{C}\end{array}$ & $\begin{array}{l}\mathrm{O}_{2} \\
\% \text { vol. }\end{array}$ & $\begin{array}{l}\Delta \mathrm{O}_{2} \\
\% \text { vol. }\end{array}$ & $\begin{array}{l}\mathrm{CO}_{2} \\
\% \text { vol. }\end{array}$ & $\mathrm{CO}$ ppm & $\begin{array}{l}\mathrm{CH}_{4} \\
\% \text { vol. }\end{array}$ \\
\hline P1 & 12.1 & 7.1 & 7.8 & 16.3 & 4.6 & 0.5 & 0 & 0 \\
\hline P2 & 11.5 & 8.8 & 8.5 & 16.3 & 4.6 & 0.47 & 0 & 0 \\
\hline P3 & 11.8 & 9.2 & 9 & 15.8 & 5.1 & 0.78 & 1 & 0 \\
\hline P4 & 9.4 & 7.5 & 8.2 & 19.4 & 1.5 & 0.16 & 0 & 0 \\
\hline P5 & 11.0 & 7.7 & 8.5 & 18.6 & 2.3 & 0.42 & 0 & 0 \\
\hline P6 & 11.2 & 6.4 & 7.5 & 3.1 & 17.8 & 5.55 & 0 & 0.236 \\
\hline
\end{tabular}


thermal activity was confirmed at the coal waste dump in Libiąż.

No significant water erosion has yet been observed on Slope 1. On its surface, there were few places where this process has only been initiated. This is due to the short time (approx. 2 months) that has elapsed since its formation. The flat part of the dump located above the slope is, however, a large catchment area for rainwater. Failure to perform drainage in this area may cause drainage of water in an uncontrolled manner and deepening of erosive gullies.

As part of the thermal state tests, two zones were found on Slope 1, in which there were clearly increased temperatures and gas concentrations. This proves the strong thermal activity of the dump in this area. The temperature in Zone 2 exceeded $270^{\circ} \mathrm{C}$ (point P6).

Thermal activity related to temperature increase was not found on Slope 2. However, strong water erosion was observed there. Numerous erosion ditches were found on Slope 2. The depth of the largest of them already reaches $1.0 \mathrm{~m}$. The lack of effective drainage of the slope and the lack of a biological cover on its surface will probably cause further development of erosion processes.

In subsequent measurement cycles planned in the TEXMIN project, the progress of water erosion and changes in the thermal state within the analyzed slopes will be assessed.

\section{Conflicts of interest}

None declared.

\section{Ethical statement}

The authors state that the research was conducted according to ethical standards.

\section{Funding body}

This project has received funding from the Research Fund for Coal and Steelunder grant agreement No. 847250 TEXMIN The Impact of Extreme Weather Events on Mining Operations.

Scientific work published as part of an international project co-funded by the Ministry of Science and Higher Education entitled " $P M W$ " in the years 2019-2022 contract No. 5009/FBWiS/2019/2.

\section{References}

[1] Web Soil. SoilWeb/Soil Management/Soil Erosion. Available online: The University of British Columbia; 2003. http://wiki.
ubc.ca/LFS:SoilWeb/Soil_Management/Soil_Erosion. [Accessed 30 October 2020].

[2] Wang H, Dlugogorski BZ, Kennedy EM. Coal oxidation at low temperatures: oxygen consumption, oxidation products, reaction mechanism and kinetic modelling. Prog Energy Combust Sci 2003;29(6):487-513. https://doi.org/10.1016/ S0360-1285(03)00042-X.

[3] Saranczuk WI. Borba s gorienijem parodnych otwałow. Kijów: Naukowa Dumka; 1978.

[4] Grossman SL, Davidi S, Cohen H. Emission of toxic and fire hazardous gases from open air coal stockpiles. Fuel 1994;73: 1184-8. https://doi.org/10.1016/0016-2361(94)90257-7.

[5] Wang $\mathrm{H}$, Dlugogorski BZ, Kennedy EM. Examination of $\mathrm{CO}_{2}, \mathrm{CO}$, and $\mathrm{H}_{2} \mathrm{O}$ formation during low-temperature oxidation of a bituminous coal. Energy Fuels 2002;16:586-92. https://doi.org/10.1021/ef010152v.

[6] Huggins FE, Huffman GP. Coal weathering and oxidation: the early stages. In: Nelson CR, editor. Chemistry of coal weathering. vol. 14. Amsterdam: Elsevier; 1989. p. 33-60.

[7] Berzelius Plott M. Final Report Dep. Spont. Comb. London; 1929.

[8] Liu C, Li S, Qiao Q, Wang J, Pan Z. Management of spontaneous combustion in coal mine waste tips in China. Water Air Soil Pollut 1998;103:441-4. https://doi.org/10.1023/A: 1004922620264.

[9] Gogola K, Rogala T, Magdziarczyk M, Smoliński A. The Mechanisms of Endogenous Fires Occurring in Extractive Waste Dumping Facilities. Sustainability 2020;12:2856. https://doi.org/10.3390/su12072856.

[10] Łączny MJ, Olszewski P, Gogola K, Bajerski A. Factors affecting the choice of fire-protection technologies used on the coal waste dumps. J Sustain Min 2011;4:87-102.

[11] Kuna-Gwoździewicz P. Emission of polycyclic aromatic hydrocarbons from the exhalation zones of thermally active mine waste dumps. J Sustain Min 2013;12(1):7-12. https:// doi.org/10.7424/jsm130103.

[12] Sułkowski J, Drenda J, Różański Z, Wrona P. Noticed in mining areas, environmental hazard connected with outflow of gases from abandoned mines and with spontaneous ignition of coal waste dumps. Gospodarka Surowcami Mineralnymi 2008;24(3/1):319-34.

[13] Różański Z. Fire hazard in coal waste dumps - selected aspects of the environmental impact. IOP Conf Ser: Earth Environ Sci. In: Proceedings of the 4th Polish Mining Congress. vol. 174. Poland: Kraków; 2017. p. 1.

[14] Howaniec N, Kuna-Gwoździewicz P, Smoliński A. Assessment of emission of selected gaseous components from coal processing waste storage site. Sustainability 2018;10(3):744. https://doi.org/10.3390/su10030744.

[15] Sui L, Wang X, Zhao D, Qu J. Application of 3D laser scanner for monitoring of landslide hazards (PART B1). Available online: Int Arch Photogram Rem Sens Spatial Inform Sci 2008;37. https://www.isprs.org/proceedings/XXXVII/ congress/1_pdf/46.pdf. [Accessed 30 October 2020].

[16] Pilecki R. Zastosowania naziemnego skanera laserowego. Czasopismo Techniczne. Mechanika 2012;109:9.

[17] Głowienka E, Jankowicz B, Kwoczyńska B, Kuras P, Michałowska K, Mikrut S, et al. Fotogrametria i skaning laserowy w modelowaniu 3D. Rzeszów: Publisher: Wyższa Szkoła Inżynieryjno-Ekonomiczna; 2015. p. 148. ISBN: 978-83-60507-26-1.

[18] Mikrut S. Classical Photogrammetry and UAV - Selected Ascpects. Int Arch Photogramm Remote Sens Spatial Inf Sci 2016;XLI-B1:947-52. https://doi.org/10.5194/isprs-archivesXLI-B1-947.

[19] Mikrut S, Głowienka-Mikrut E, Michałowska K. The UAV technique as a future direction of development of low-ceiling aerial photogrammetry. Geomatics Environ Eng 2013;7(4): 69-77. https://doi.org/10.7494/geom.2013.7.4.69.

[20] Gong C, Lei S, Bian Z, Liu Y, Zhang Z, Cheng W. Analysis of the Development of an Erosion Gully in an Open-Pit Coal Mine Dump During a Winter Freeze-Thaw Cycle by Using 
Low-Cost UAVs. Remote Sens 2019;11:11. https://doi.org/ $10.3390 / r s 11111356$.

[21] Różański Z, Konior J, Balcarczyk L. Testing the in situ Bulk Density of Mining Waste Stored in Dumping Grounds. Pol J Environ Stud 2019;28:3. https://doi.org/10.15244/pjoes/84863.

[22] Balcarczyk L, Różański Z. Bezinwazyjne pomiary termowizyjne 3D - skanowanie laserowe i fotogrametria. POI Format/ Politechnika Śląska. Konferencja Środowisko Informacji. Available online: Warszawa: Centrum Nauki Kopernik; 22.11.2018. https://ekoportal.gov.pl/konferencja-srodowiskoinformacji/prezentacje-1. [Accessed 30 October 2020].

[23] Rysbekov K, Huayang D, Kalybekov T, Sandybekov M, Idrissov K, Zhakypbek Y, et al. Application features of the surface laser scanning technology when solving the main tasks of surveying support for reclamation. Min Miner Deposits 2019;13(3):40-8. https://doi.org/10.33271/ mining13.03.040.
[24] Baiocchi V, Napoleoni Q, Tesei M, Servodio G, Alicandro M, Costantino D. UAV for monitoring the settlement of a landfill. Eur J Remote Sens 2019;52(sup3):41-52. https:// doi.org/10.1080/22797254.2019.1683471.

[25] Łączny JM, Baran J, Ryszko A. Opracowywanie i wdrażanie innowacyjnych technologii środowiskowych stosowanych na zwałowiskach odpadów powęlowych. Podstawy teoretyczno-metodyczne i przykłady praktyczne. Radom: Wydawnictwo Naukowe ITEPIB; 2012.

[26] Parafiniuk J. Środowiska ekshalacji wulkanicznych i płonących hałd węglowych -mineralogiczne studium porównawcze. Biuletyn Państwowego Instytutu Geologicznego 2012;452:225-36.

[27] Ciesielczuk J, Janeczek J, Cebulak S. Przebieg i przyczyny endogenicznego pożaru węla kamiennego na zrekultywowanym składowisku odpadów komunalnych w Katowicach. Przegląd Geologiczny 2013;61(12):764-72. 